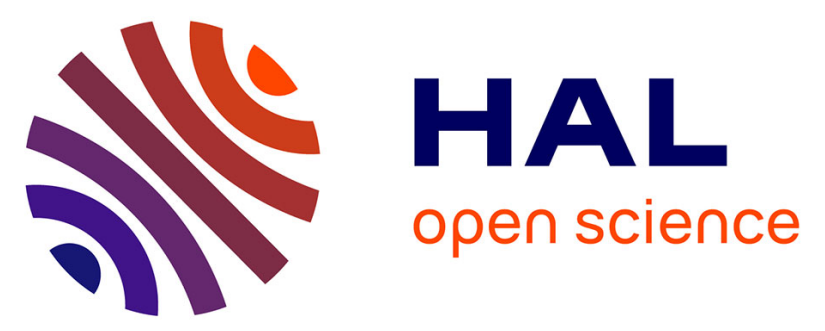

\title{
Quantitative proteome profiling of dystrophic dog skeletal muscle reveals a stabilized muscular architecture and protection against oxidative stress after systemic delivery of MuStem cells.
}

Aurélie Lardenois, Sabrina Jagot, Mélanie Lagarrigue, Blandine Guével, Mireille Ledevin, Thibaut Larcher, Laurence Dubreil, Charles Pineau, Karl Rouger, Laétitia Guével

\section{- To cite this version:}

Aurélie Lardenois, Sabrina Jagot, Mélanie Lagarrigue, Blandine Guével, Mireille Ledevin, et al.. Quantitative proteome profiling of dystrophic dog skeletal muscle reveals a stabilized muscular architecture and protection against oxidative stress after systemic delivery of MuStem cells.. Proteomics, 2016, 16 (14), pp.2028-2042. 10.1002/pmic.201600002 . hal-01332030

\author{
HAL Id: hal-01332030 \\ https://hal.science/hal-01332030
}

Submitted on 18 Oct 2016

HAL is a multi-disciplinary open access archive for the deposit and dissemination of scientific research documents, whether they are published or not. The documents may come from teaching and research institutions in France or abroad, or from public or private research centers.
L'archive ouverte pluridisciplinaire HAL, est destinée au dépôt et à la diffusion de documents scientifiques de niveau recherche, publiés ou non, émanant des établissements d'enseignement et de recherche français ou étrangers, des laboratoires publics ou privés. 
Quantitative proteome profiling of dystrophic dog skeletal muscle reveals a stabilized muscular architecture and protection against oxidative stress after systemic delivery of MuStem cells

Aurélie Lardenois, ${ }^{1,2}$ Sabrina Jagot, ${ }^{1,2,3}$ Mélanie Lagarrigue, ${ }^{4,5}$ Blandine Guével, ${ }^{4,5}$ Mireille Ledevin, ${ }^{1,2}$ Thibaut Larcher, ${ }^{1,2}$ Laurence Dubreil, ${ }^{1,2}$ Charles Pineau, ${ }^{4,5}$ Karl Rouger $^{1,2,6}$ and Laëtitia Guével ${ }^{*, 1,2,3,6}$

'INRA, UMR703 PAnTher, Nantes, France

²LUNAM Université, Oniris, École nationale vétérinaire, agro-alimentaire et de l'alimentation NantesAtlantique, Nantes, France

${ }^{3}$ Université de Nantes, Nantes, France

4Protim, Irset Inserm UMR 1085, Campus de Beaulieu, F-35042 Rennes Cedex, France

5Université de Rennes I, Campus de Beaulieu, F-35042 Rennes Cedex, France

${ }^{6}$ These authors contributed equally

Correspondence : Dr. Laëtitia Guével, INRA, UMR703 PAnTher, Ecole Nationale Vétérinaire, Agroalimentaire et de l'Alimentation, Nantes-Atlantique (Oniris), Atlanpole- La Chantrerie; CS. 40706, 44307 Nantes Cedex 3, France.

Phone: +33 (0)2 406878 74. Fax: +33 (0)2 40180002 .

E-mail : laetitia.guevel@univ-nantes.fr

Abbreviations : BCA, bicinchoninic acid; DMD, Duchenne Muscular Dystrophy; GRMD, Golden Retriever Muscular Dystrophy; ICPL, isotope-coded protein label; Hyp, Hydroxyproline

Keywords : cell therapy, Duchenne Muscular Dystrophy, GRMD dog model, ICPL, muscle stem cell

Total number of words : 8500

The mass spectrometry proteomics data have been deposited with the ProteomeXchange Consortium via the PRIDE partner repository, under the dataset identifier PXD001768: 
Abstract

Proteomic profiling plays a decisive role in the elucidation of molecular signatures representative of a specific clinical context. MuStem cell-based therapy represents a promising approach for clinical applications to cure Duchenne Muscular Dystrophy (DMD). To expand our previous studies collected in the clinically relevant DMD animal model, we decided to investigate the skeletal muscle proteome four months after systemic delivery of allogenic MuStem cells. Quantitative proteomics with isotopecoded protein labelling (ICPL) was used to compile quantitative changes in the protein expression profiles of muscle in transplanted Golden Retriever Muscular Dystrophy (GRMD) dogs as compared to GRMD dogs. A total of 492 proteins were quantified, including 25 that were overrepresented and 46 that were underrepresented after MuStem cell transplantation. Interestingly, this study demonstrates that somatic stem cell therapy impacts on the structural integrity of the muscle fascicle by acting on fibres and its connections with the extracellular matrix. We also show that cell infusion promotes protective mechanisms against oxidative stress and favours the initial phase of muscle repair. This study allows us to identify putative candidates for tissue markers that might be of great value in objectively exploring the clinical benefits resulting from our cell-based therapy for DMD.

Statement of significance of the study

Our study is the first large-scale proteomics study following the intra-arterial delivery of MuStem cells in GRMD dogs, which represent a clinically relevant animal model for Duchenne Muscular Dystrophy. We have demonstrated that our cell therapy has an impact on the stabilization of muscle structure organization, the protection against oxidative stress response as well as the processes of sustained muscle repair. Furthermore, our findings shed light on skeletal muscle tissue remodelling. We have also identified new promising biomarkers that could be used as outcome measures when assessing the efficacy of therapeutic strategies developed for muscle diseases.

1 Introduction 
The neuromuscular disorder Duchenne Muscular Dystrophy (DMD) is one of the most frequently inherited lethal diseases affecting one newborn boy in 5,500 [1]. It is caused by mutations in the dystrophin gene[2] and is characterized by severe degeneration of muscle fibres, progressive muscle weakness and paralysis, leading to respiratory and cardiac failure and ultimately, death. The dystrophin protein is localized under the sarcolemma of muscle fibres and integrated within a large multiprotein complex referred to as the dystrophin-glycoprotein complex (DGC) [3]. Dystrophin provides a strong physical link between the cytoskeleton network and the extracellular matrix.

Based on large-scale gene expression analysis, previous studies have described transcriptional changes in the skeletal muscle of individuals with DMD [4,5] and in dystrophic animals including the $m d x$ mouse [6-9] and the dog models (CXMDJ and GRMD) [10]. The gene expression signature characterizing dystrophic muscle shows an altered expression of genes involved in the inflammatory response, as well as in the remodelling of the extracellular matrix, muscle regeneration and metabolism $[5,11,12]$. Comparative proteomic analysis of tissue from established animal models, such as the $m d x$ mouse and the GRMD dog, have led to crucial contributions in the field of muscular dystrophy research, allowing us to explore the complexity of the various pathophysiological steps involved in this monogenic disorder [13-16]. Changes in the concentration of muscle proteins provide novel insights into the molecular pathology of the disease [15]. Increasing evidence suggests that secondary mechanisms, such as the alteration of key signaling and metabolic pathways, may play an important role.

To investigate potential therapies for DMD boys, preclinical studies are commonly performed using the GRMD dog model, which is characterized by a rapid progression of clinical dysfunction and severe muscle tissue remodeling $[17,18]$. GRMD dogs harbor a mutation in the dystrophin gene and show the typical histological features of a dystrophic process, with repeated cycles of muscle necrosis and regeneration, variability in fibre size, splitting, progressive fibrosis and fatty infiltration [19]. Moreover, GRMD dogs show most of the signs found in the human disease, among them muscle wasting, postural abnormalities and premature death, positioning GRMD dog as the clinically relevant animal model for DMD [19-22]. Secondary to repeated cycles of degeneration/regeneration of muscle fibre, muscle fibrosis leads to biomechanical adaptation that impairs the gait function [23]. A wide inter-individual variability also figures among the numerous similarities shared by canine and human diseases [24]. This heterogeneity is a criteria limiting strongly the identification of targets of interest but finally increases their robustness as putative candidates for tissue markers. In a dystrophic context, patients exhaust their satellite cell reserves due to continuous cycles of muscle injury and regeneration, and muscles become less able to repair themselves [25]. A number of experimental therapies have been developed in the GRMD dog model to enhance the process of muscle fibre regeneration $[20,26]$. Several adult stem cell populations providing efficient muscle regeneration in a dystrophic context impact numerous biological processes to maintain an intense muscle fibre regeneration activity, and thus represent attractive candidates for therapeutic approaches [2735]. In a non-pathological context, skeletal muscle repair is a highly synchronized process involving the activation of various cellular and molecular responses, where the coordination between inflammation and regeneration is crucial for the beneficial outcome of the repair process $[36,37]$. 
Recently, we have shown that systemic delivery of MuStem cells, represent an attractive avenue for future therapeutic applications in individuals with DMD [38]. Importantly, they allow persisting stabilization of clinical status and histological remodeling of the skeletal muscle of MuStem celltransplanted GRMD dogs (denoted as GRMD ${ }^{\text {Mustem }}$ ). However, these effects are linked to a relative low dystrophin protein level and a low percentage of dystrophin-positive muscle fibres that clearly evoke the implication of other molecular mechanisms to explain the mode of action of the MuStem cells. We have recently shown the impact of MuStem cell transplantation on several biological pathways based on a selection of 31 genes displaying expression signals specifically modulated by the cell therapy. MuStem cell delivery is associated with an up-regulation of genes playing a role in the enhancement of skeletal muscle fibre regeneration. Simultaneously, we observed an overrepresentation of ubiquitin-mediated protein reflecting a more active degradation process of the damaged tissue [10].

To obtain a fuller understanding of the impact of the systemic delivery of MuStem cells on the skeletal muscle of GRMD dog, we performed a similar approach at a proteome level using quantitative proteomics. The ICPL experiment described here reveals a significant overrepresentation of 25 proteins and a significant underrepresentation of 46 proteins when comparing the skeletal muscle of GRMD $^{\text {Mustem }}$ dogs with mock dogs (GRMD). The ICPL approach generates results that are entirely complementary to the analysis carried out at the transcript level, paving the way to understanding the efficacy of MuStem cell therapy on dystrophic dogs.

\section{Materials and methods}

\subsection{Animals}

The animals formed part of a GRMD dog-breeding colony established in France. They were housed and cared for at the Boisbonne Center for Gene and Cell Therapy at Oniris (Nantes, France) according to protocols in compliance with the principles set out in the guidelines of the French National Institute for Agronomic Research (INRA) for the care and use of laboratory animals in biological experimentation. Nine-month-old dogs were included in this proteomic study, including three healthy, three GRMD and three GRMD ${ }^{\text {Mustem }}$ dogs (Table S1, Supporting information). The western blot experiments were performed using three additional GRMD ${ }^{\text {Mustem }}$ dogs.

\subsection{Skeletal muscle protein extraction and ICPL labelling}

The medial portion of the biceps femoris muscle was sampled during a complete necropsy of each dog. Samples were divided into two parts, one immediately frozen in liquid nitrogen, and stored at $80^{\circ} \mathrm{C}$ until processing, and another frozen in isopentane cooled by liquid nitrogen for immonuhistochemistry and histoenzymology. For protein extraction, muscle sample were used after careful removal of fibrotic portions, and were homogenized in RIPA lysis buffer containing $150 \mathrm{mM} \mathrm{NaCl}, 50$ $\mathrm{mM}$ Tris- $\mathrm{HCl} \mathrm{pH} 7.4,1 \%$ Nonidet-P40, 1\% glycerol, $1 \mathrm{mM}$ EDTA and protease inhibitors using the PreCellys (Ozyme, France) $2 \times 10 \mathrm{sec}, 6,500 \mathrm{rpm}$. Homogenates were centrifuged at 10,000 g to pellet debris and supernatants were centrifuged at $20,000 \mathrm{~g}$ for $45 \mathrm{~min}$ at $4^{\circ} \mathrm{C}$ to enrich in cytosolic proteins. Protein concentration was determined using a BCA protein assay (Sigma-Aldrich, SaintQuentin-Fallavier, France). A total of $100 \mu \mathrm{g}$ of cytosolic proteins were purified by TCA/acetone, 
10:90 precipitation at $-20^{\circ} \mathrm{C}$ overnight. After centrifugation $\left(15,000 \mathrm{~g}, 30 \mathrm{~min}, 4^{\circ} \mathrm{C}\right)$, supernatants were discarded and the remaining acetone was removed by evaporation at room temperature (RT). Protein pellets were then dissolved in $6 \mathrm{M}$ guanidine $\mathrm{HCl}, \mathrm{pH}$ 8.5. Protein concentration was determined using the Bradford assay (Sigma-Aldrich) and adjusted to $4.1 \mathrm{mg} / \mathrm{mL}$ in all samples.

Triplex experiments were performed on three biological replicates of GRMD and three biological replicates of treated GRMD. For each triplex, the same healthy sample constituted of a pool of skeletal muscle from three healthy dogs was used. ICPL labelling of proteins was performed according to the manusfacturer's instructions using the Serva ICPL Quadruplex Kit (Serva, Heidelberg, Germany). Protein disulphide bonds were reduced for $30 \mathrm{~min}$ at $60^{\circ} \mathrm{C}$ by adding $0.5 \mu \mathrm{L}$ of $0.2 \mathrm{M}$ tris (2carboxyethyl) phosphine to $20 \mu \mathrm{L}$ of each protein sample. Free cysteines were then alkylated for 30 min at RT in the dark using $0.5 \mu \mathrm{L}$ of $0.4 \mathrm{mM}$ iodoacetamide. The excess iodoacetamide was quenched for $15 \mathrm{~min}$ at RT by adding $0.5 \mu \mathrm{L}$ of $0.5 \mathrm{mM} \mathrm{N}$-acetyl-cysteine. Lysine residues were labelled at RT for $2 \mathrm{~h}$ by adding respectively $3 \mu \mathrm{L}$ of light (12C-nicotinoyloxysuccinimide, 105.02 Da, L), heavy (13C6-nicotinoyloxysuccinimide, $111.04 \mathrm{Da}, \mathrm{H}$ ) or super-heavy (13C62D4-

nicotinoyloxysuccinimide, $115.04 \mathrm{Da}, \mathrm{SH}$ ) labels to the three respective samples. Labels were permutated for the three biological replicates (Table S1, Supporting Information). Remaining reagents were quenched for $20 \mathrm{~min}$ at RT using $2 \mu \mathrm{L}$ of $6 \mathrm{mM}$ hydroxylamine. Esters formed during the labelling procedure were hydrolysed by raising the $\mathrm{pH}$ to 12 with $1 \mathrm{M} \mathrm{NaOH}$ for $20 \mathrm{~min}$. The three labelled samples were then combined and the proteins were purified by acetone precipitation at $-20^{\circ} \mathrm{C}$ overnight. The mixture was centrifuged at $15,000 \mathrm{~g}$ for $30 \mathrm{~min}$ at $4^{\circ} \mathrm{C}$. The supernatant was discarded and remaining acetone removed by evaporation at RT. The protein pellet was then dissolved in $20 \mathrm{mM}$ HEPES at $\mathrm{pH}$ 9, with a final protein concentration of $2.5 \mathrm{mg} / \mathrm{mL}$.

Labelled proteins $(50 \mu \mathrm{g}$ ) were separated by SDS-PAGE using a 12\% precast gel (NuPage, Life Technologies, Illkirch, France). The gel was fixed in 30\% ethanol, 10\% acetic acid for 15 min, washed in water for $15 \mathrm{~min}$ and stained with Coomassie blue using the EZBlue gel staining reagent (SigmaAldrich). The entire gel lane (including the stacking part for the large proteins) was manually cut into 20 pieces of equal size. The 20 bands excised from the gel were washed with $\mathrm{H}_{2} \mathrm{O}, 100 \mathrm{mM} \mathrm{NH}_{4} \mathrm{HCO}_{3}$, $50 \mathrm{mM} \mathrm{NH}_{4} \mathrm{HCO}_{3}$ in ACN/water, 1:1 and dehydrated with $100 \% \mathrm{ACN}$. In-gel digestion was performed overnight at $37^{\circ} \mathrm{C}$ with modified trypsin (Promega, Charbonnieres, France) at $4 \mathrm{ng} / \mu \mathrm{L}$ in $50 \mathrm{mM}$ $\mathrm{NH}_{4} \mathrm{HCO}_{3}$. Extraction of digestion peptides was then performed by sequential incubation in the following solutions: $A C N / \mathrm{H}_{2} \mathrm{O} /$ TFA, 70:30:0.1 then 100\% $\mathrm{ACN}$ and $\mathrm{ACN} / \mathrm{H}_{2} \mathrm{O} / \mathrm{TFA}, 70: 30: 0.1$. Extracts were concentrated by evaporation in a SpeedVac to reach a final volume of $30 \mu \mathrm{L}$.

\subsection{LC-MS/MS analysis}

Mobile $A\left(\mathrm{H}_{2} \mathrm{O} /\right.$ formic acid, 100:0.1) and B (ACN/formic acid, 100:0.1) phases for HPLC were delivered by the Ultimate 3000 nanoflow LC system (ThermoScientific Dionex, Courtaboeuf, France). Ten $\mu \mathrm{L}$ of peptide mixture were loaded on a trapping precolumn $(5 \mathrm{~mm} \times 300 \mu \mathrm{m}$ i.d., $300 \AA ̊$ pore size, Pepmap C18, $5 \mu \mathrm{m}$, ThermoScientific Dionex) for 3 min in $2 \%$ buffer B at a flow rate of $25 \mu \mathrm{L} / \mathrm{min}$. This step was followed by reverse-phase separations at a flow rate of $0.250 \mu \mathrm{L} / \mathrm{min}$ using an analytical column (15 cm × $75 \mu \mathrm{m}$ i.d., 300 Å pore size, Pepmap C18, $5 \mu \mathrm{m}$, ThermoScientific Dionex). We ran a gradient ranging from $2 \%$ to $35 \%$ of $B$ for the first $60 \mathrm{~min}, 35 \%$ to $60 \%$ of $B$ from $\min 60-85$, and 
$60 \%$ to $90 \%$ of B from min $85-105$. Finally, the column was washed with $90 \%$ of B for 16 min, and with $2 \%$ of $B$ for 19 min prior to loading of the next sample. The peptides were detected by direct elution from the HPLC column to the electrospray ion source of the LTQ-Orbitrap XL mass spectrometer (ThermoScientific Dionex). An ESI voltage of $1.4 \mathrm{kV}$ was applied to the HPLC buffer using the liquid junction provided by the nanoelectrospray ion source, and the ion transfer tube temperature was set at $200^{\circ} \mathrm{C}$. The LTQ-Orbitrap XL instrument was operated in its data-dependent mode by automatically switching between full survey scan MS and consecutive MS/MS acquisition. Full survey scan MS spectra (mass range 400-2,000) were acquired in the Orbitrap section of the instrument with a resolution of $r=60000$ at $\mathrm{m} / \mathrm{z} 400$; ion injection times are calculated for each spectrum to allow for the accumulation of $10^{6}$ ions in the Orbitrap. The 10 most intense peptide ions in each survey scan, with an intensity above 2,000 counts and a charge state $\geq 2$, were sequentially isolated and fragmented in the linear ion trap by collision-induced dissociation. Normalized collision energy was set to $35 \%$ with an activation time of $30 \mathrm{~ms}$. Peaks selected for fragmentation were automatically entered on a dynamic exclusion list for $60 \mathrm{~s}$ with a mass tolerance of $\pm 10 \mathrm{ppm}$.

\subsection{Identification and relative quantification of proteins}

MS data were saved in RAW file format using XCalibur 2.0.7 (ThermoScientific Dionex) with Tune 2.4 acquisition software. The data analysis was performed with the Proteome Discoverer 1.2 software supported by Mascot (Mascot server v2.2.07; http://www.matrixscience.com) database search engines for peptide and protein identification. For each ICPL triplex experiment, the 20 RAW files corresponding to the 20 excised bands were submitted to database searching. MS/MS spectra were compared to the Canis familiaris Uniprot Reference Proteome database (UP000002254, August 2014, 25440 sequences, 14669653 residues). Mass tolerances for MS and MS/MS were set at 10 ppm and $0.5 \mathrm{Da}$, respectively. As the modification of lysine residues by ICPL labelling prevents the cleavage of lysine residues by trypsine, arginine $\mathrm{C}$ (which only cleaves the arginine residues) was selected as enzyme with one allowed miscleavage. Protein modifications were fixed carbamidomethylation of cysteines, variable oxidation of methionine, variable light, heavy and super-heavy ICPL labels of lysine and N-terminus of proteins and variable acetylation of lysine and N-terminus of proteins. Identified peptides were filtered by Proteome Discoverer according to the ion score to obtain a false discovery rate of $5 \%$ using the automatic decoy database search. Only rank 1 peptides were considered. In the case of peptides shared by different proteins, proteins were automatically grouped by Proteome Discoverer as follows: the proteins within a given group were ranked according to their protein score and the top protein was reported in the protein table. Only unique peptides (i.e. those not shared between different identified proteins) were considered by ProteomeDiscoverer (ThermoScientific Dionex) for relative quantification. Quantification was performed if at least one quantification channel was identified. Missing quantification values were automatically replaced by the minimum intensity detected by ProteomeDiscoverer.

\subsection{ICPL data pre-processing}

The ICPL experiment was designed as biological triplicates of triplex samples composed of skeletal muscle from one pool of healthy sample, one GRMD dog and one GRMD ${ }^{\text {Mustem }}$ dog (see Table S1, Supporting Information). Among the non-redundant 1058 proteins quantified across the three tri- 
plex ICPL experiments, 492 proteins were quantified by at least two distinct peptides in at least two out of the three triplex and were further considered in the analysis (Fig. S1, Supporting Information). Relative quantification of proteins was performed by considering the GRMD versus healthy samples ratio and the GRMD ${ }^{\text {Mustem }}$ versus GRMD samples as follows. First, the different peptide ratios were log2-transformed. In the case of a labelled peptide identified several times in a triplex experiment, the median of all log2-transformed ratios attributed to this peptide sequence was calculated. Peptides with different modifications or charge state, but with the same amino acid sequence, were counted as a single peptide. The relative quantification of each protein in a triplex experiment was then estimated as the median of the log2-transformed ratios of all the peptides assigned to this protein. This protein ratio was estimated for each of the 492 proteins, and then further analyzed using the Annotation, Mapping, Expression and Network (AMEN) suite of tools [39]. The log2-transformed protein ratios were homogeneously distributed across the samples (Fig. S2A, Supporting Information). These protein ratios were then normalized using the "quantile-quantile" method (Fig. S2B, Supporting Information).

\subsection{Statistical filtering and classification}

The technical variability of the ICPL experiment was evaluated similarly to previous work $[40,41]$. A part of the pool of skeletal muscle from three healthy dogs was divided in three aliquots. Each aliquot was labelled with the light, heavy and super heavy ICPL, respectively. Labeled aliquots were mixed in a 1:1:1 ratio and separated by SDS-PAGE using a 12\% precast gel. The entire gel lane was manually cut into 20 pieces then subjected to in-gel digestion with trypsin. Digestion peptides were extracted and analysed by LC-MS/MS. The data were pre-processed as described in the previous section. The distribution of the ratio data across the samples is illustrated before and after normalization (Fig. S2C-D). Among the 462 initial proteins, 212 were identified as relevant quantified proteins. The technical variability was fixed at 2 standard deviations that corresponded to a maximum of 1.19 (or 0.25 in log2 scale) (Fig. S2E).

To estimate biological variability, the quantified proteins yielding a ratio of $\geq 1.5$ (or a log2transformed ratio $\geq 0.58$ ) in at least two triplex or yielding a median ratio $\geq 1.5$ when they were quantified in only two triplex out of the three were selected (Fig. S2F). A LIMMA statistical test was then used to identify the proteins that were significantly differentially expressed (F-value adjusted with the False Discovery Rate, $p \leq 0.05$ ) [42]. The resulting proteins were then classified into groups associated with over- or under-expressed based on the ratios obtained when comparing the GRMD versus the healthy dog muscle and when comparing the GRMD ${ }^{\text {Mustem }}$ versus the GRMD dog muscle (Fig. 1).

\subsection{Functional analysis}

The enrichments of the Gene Ontology (GO) terms within the protein groups were calculated with AMEN with the Fisher exact probability using the Gaussian Hypergeometric test [39]. A term was considered to be significantly over-represented compared to the whole dog proteome when the 
number of proteins in the group with this annotation was $\geq 5$ and when the associated FDR-corrected p-value was $\leq 0.05$.

\subsection{Immunoblotting analysis}

To validate the expression changes of four proteins detected by proteomic analyses, immunoblotting experiments were performed on necropsies from three healthy, three GRMD and six GRMD Mustem dogs. Cytosolic protein extracts were resolved by sodium dodecyl sulphate polyacrylamide gel electrophoresis (SDS-PAGE) on 4-12\% polyacrylamide gels (Nupage, Life Technologies, Illkirch, France) and electroblotted onto nitrocellulose membranes (Protran BA 83, GE Healthcare, Orsay, France) using a BioRad ${ }^{\circledR}$ (Marnes-la-Coquette, France) liquid blotting system at $300 \mathrm{~mA}$ for $2 \mathrm{~h}$. The membranes were blocked using 50\% Blocking Buffer (Odyssey ${ }^{\circledR}$, Li-COR Biosciences, Lincoln, NE) in PBS, for $1 \mathrm{~h}$ at RT and incubated overnight at $4^{\circ} \mathrm{C}$ with primary antibodies against myosin, heavy chain 7 (MYH7, ab11083, Abcam, Cambridge, MA), gelsolin (GSN, ab2969, Millipore, Billerica-MA), troponin T type 1 (TNNT1, ab155028, Abcam), ferritin light chain (ab69090, Abcam) and $\alpha$-actinin (A7811, Sigma-Aldrich) using dilutions recommended by the manufacturer. After washing with Tween $0.1 \%$ in PBS, the blots were incubated with horseradish peroxydase-conjugated or fluorophore-conjugated anti-mouse and anti-rabbit secondary antibody. Equal protein loading was verified by $\alpha$-actinin labelling and a Ponceau red staining of the membranes. The western blot bands were scanned and analysed with Odyssey ${ }^{\circledR}$.

\subsection{Integration of transcriptomics data}

The AMEN suite of tools [39] was used to convert the Uniprot identifiers into Agilent microarray probes based on the annotation file used in our previous study [10]. This tool was also used to identify the entities differentially expressed at both the transcriptomic and the proteomic level.

\subsection{Immunohistochemistry and histoenzymology}

Two serial transversal cryosections were incubated (overnight, $4^{\circ} \mathrm{C}$ ) with primary antibody against the developmental isoform of myosin heavy chain (MyHCd, 1:100, NCL-MHCd, Novocastra) or the MYH7 (1:5,000, ab11083, Abcam). For MyHCd, the sections were incubated for $1 \mathrm{~h}$ at RT with biotinylated goat anti-mouse and streptavidin horseradish peroxidase. A peroxidase conjugated goat anti-mouse antibody was used as secondary antibody against MYH7. The revelation was carried out using DAB (3,3'-diaminobenzidine) chromogen 5 or 10 min at RT for MYH7 and MyHCd, respectively. After washing, the samples were coverslipped with Mowiol Medium (Calbiochem EMD Biosciences, San Diego, CA) and scanned with a blue $488 \mathrm{~nm}$ argon ion laser using an C1 inverted Nikon TE-2000 laser scanning confocal microscope (Champigny, France). To evaluate the distribution pattern of the muscle fibre types, the myofibrillar ATPase (mATPase) reaction was used with acid preincubation ( $\mathrm{pH}$ 4.35). Slow type I fibres stain black whereas fast type Ilb muscle fibres remain colorless and intermediate type Ila fibres stain shades of grey at $\mathrm{pH}$ 4.35. For this reaction, adenosine 5 triphosphate was used as the enzymatic substrate (A2383, Sigma-Aldrich). For Collagen I immunolabelling, transverse cryosections were incubated (overnight, $4^{\circ} \mathrm{C}$ ) with the primary $\mathrm{Ab}$ against collagen I (1:500, MP Biomedicals, Illkirch, France). Sections were then incubated (1 hour at room temperature) with Alexa fluor 488-conjugated goat anti-mouse IgG (1:300, Life Technologies), then with the fluorescent DNA- 
dye DRAQ5 (15 min, room temperature, 1:1,000, Biostatus, Leicestershire, UK) before mounting. Immunofluorescence was observed with a laser scanning confocal microscope (Zeiss LSM 780, Carl Zeiss Microscopy GmbH, lena, Germany).

\subsection{Histomorphometric analysis}

Quantitative analysis was performed using the Fiji open-source platform for image analysis [43]. Surface area recovered by collagen immunolabelling was quantified from confocal images. Intraobserver agreement was tested by reproducing five times the measure on the same sample. The resulting variation coefficient was $9.4 \%$. Repeated-Measures ANOVA were carried out on the three groups. Proportions of slow, fast and intermediate fibres were quantified from binarized images obtained after thresholding. Evaluation of the percentage of $\mathrm{MYH}^{+}$muscle fibres was also determined by adjusting the threshold value to classified fibres as MYH7 positive or negative. The images were obtained with a bright-field image analysis station (Eclipse 90i Nikon). At least 300 fibres were counted for each muscle.

\subsection{Hydroxyproline assay}

Hydroxyproline (Hyp) assays were used as a measure of collagen content using the Hydroxyproline assay kit (Sigma-Aldrich). The frozen biceps femoris section was weighed and placed in a sealed tube containing $6 \mathrm{M} \mathrm{HCl}$. Briefly, the tissue was hydrolyzed overnight at $110^{\circ} \mathrm{C}$ before being dried using low heat $\left(60^{\circ} \mathrm{C}\right)$ and the assay was performed according to the manufacturer's insctructions. Values are expressed as micrograms of Hyp per milligram of wet tissue weight. Absorbance was read at 562 $\mathrm{nm}$ and HP content was calculated from a standard curve. Repeated-Measures ANOVA were carried out on the three groups.

\subsection{Data availability}

The raw data obtained from the mass spectrometry proteomics have been deposited into the ProteomeXchange Consortium [44] via the PRIDE partner repository, under the dataset identifier PXD001768.

\section{Results}

3.1 MuStem cell systemic delivery is associated with a complex differential proteome signature of GRMD dog skeletal muscle

The administration of three consecutive intra-arterial injections of MuStem cells in the GRMD dogs was associated with a global and persistent improvement of the clinical status $[10,38]$. To investigate the consequences of MuStem cell transplantation on the muscle proteome of GRMD dogs, we performed an ICPL experiment comparing the tissues of 9-month-old healthy, GRMD and GRMD ${ }^{\text {Mustem }}$ dogs. This quantitative proteomic approach allowed the identification and quantification of 2648 peptides, corresponding to 1058 proteins. Out of these identified peptides, the pre-processing step leads us to consider 2288 peptides or 492 proteins in the following analysis (File S1). A comparison of 
the GRMD with the healthy samples allows us to identify 224 differentially expressed proteins and 118 proteins with statistically significant differential expression. Among these latter, 45 are overexpressed and 73 are under-expressed in the skeletal muscle of the GRMD dogs compared to the healthy dogs. Figure 1 illustrates the effect of MuStem cell administration into the skeletal muscle of GRMD dogs. Moreover, the statistical filtering of the 492 proteins reveals 158 proteins showing a variation of expression of $\geq 1.5$ between the GRMD ${ }^{\text {Mustem }}$ and GRMD dog samples. Among these proteins, 71 are significantly differentially expressed (File S2) and can be classified into a group of 25 over-expressed proteins (Table 1) and a group of 46 under-expressed proteins (Table 2). It is interesting to note that, after MuStem cell transplantation, the APOE protein displays the highest overrepresentation, since a delayed skeletal muscle regeneration has been observed in $\mathrm{ApoE}^{-/-}$mice after hind limb ischemia-reperfusion [45]. It is also unexpected that the most under-expressed proteins after cell therapy are structural proteins of the sarcomere such as isoforms of troponin, myosin or actin.

3.2 Functional analysis of differentially expressed proteins reveal a diffuse impact of MuStem cells in terms of biological processes

The group of 25 over-expressed proteins in the GRMD dog after MuStem cell transplantation as compared to the GRMD dog show significant enrichment in several GO terms, including regulation of angiogenesis $\left(n=5, p<5 \times 10^{-2}\right)$, focal adhesion $\left(n=5, p<4 \times 10^{-2}\right)$, wound healing $\left(n=7, p<5 \times 10^{-2}\right)$, extracellular vesicular exosome $\left(n=11, p<9 \times 10^{-3}\right)$, inflammatory response $\left(n=7, p<2 \times 10^{-2}\right)$ and response to stress $\left(n=11, p<5 \times 10^{-2}\right)$. In addition, the group of 46 under-expressed proteins is significantly enriched in GO terms (File S3) such as striated muscle cell differentiation $\left(n=16, p<4 \times 10^{-6}\right)$, sarcomere organization $\left(n=13, p<3 \times 10^{-9}\right)$, actin cytoskeleton organization $\left(n=17, p<2 \times 10^{-5}\right)$, striated muscle contraction $\left(n=12, p<6 \times 10^{-8}\right)$, slow-twitch skeletal muscle fibre contraction $\left(n=6, p<3 \times 10^{-8}\right)$, oxidationreduction process $\left(n=13, p<7 \times 10^{-4}\right)$, ATP metabolic process $\left(n=16, p<1 \times 10^{-8}\right)$, mitochondrion $(n=22$, $\left.p<3 \times 10^{-5}\right)$, organophosphate catabolic process $(n=13, p<5 \times 10-5)$, regulation of calcium ion transport into cytosol $\left(n=5, p<5 \times 10^{-2}\right)$, reactive oxygen species metabolic process $\left(n=8, p<4 \times 10^{-5}\right)$ and blood circulation $\left(n=14, p<2 \times 10^{-4}\right)$.

Among the 71 proteins significantly differentially expressed after cell transplantation, 4 were chosen for a Western immunoblot (WB) analysis according to their biological interest and dog antibody availability: MYH7, GSN, TNNT1 and ferritin (Fig. 2). In accordance with the ICPL mass spectrometry data, WB results show that expression levels of MYH7, GSN and TNNT1 are under-expressed in the GRMD $^{\text {Mustem }}$ samples as compared to the GRMD samples, and that ferritin is over-expressed after MuStem cell transplantation (Fig. 2A-C). Even if both techniques can discriminate GRMD ${ }^{\text {Mustem }}$ dog from GRMD controls based on the muscle expression level of ferritin, we observe high interindividual variations for this protein (average ICPL ratio $11.65 \pm 8.01$ and average WB ratio $3.01 \pm 1.00$ ) (Fig. 2C). Overall, the stringent criteria used to select proteins that are differentially represented in GRMD $^{\text {Mustem }}$ versus GRMD dog muscle from ICPL data (described in Fig. 1) allow us to consider these proteins as potential tissue markers for the efficacy of the MuStem cell therapy.

3.3 Composition of muscle fibre type is affected by MuStem cell transplantation 
Among the proteins differentially expressed as a result of MuStem cell administration, several proteins are described as being associated with specific fibre types or implicated in fibre type switching. MYH4 and TNNT3, markers of fast fibres (type II) are identified as under-expressed in the GRMD ${ }^{\text {Mus- }}$ tem dogs compared to the GRMD dogs. In our study, transgelin (TAGLN) is found to be overexpressed, while it has already been described as a marker of the switch from fast to slow fibre type [46]. On the other hand, MYL2 and MYH7 proteins are known as cardiac myosin but are also described as expressed in the slow fibre (type I) of skeletal muscles [47]. Both of the proteins are under-expressed in GRMD ${ }^{\text {Mustem }}$ compared to GRMD skeletal muscle, as well as TNNT1 which is known to be associated with type I fibres [48]. In return, the protein FABP4, which is described to be more abundant in endurance trained subjects [49], is identified in the present study as over-expressed. These changes of expression seem to illustrate a global change in fibre type composition of the skeletal muscle following MuStem cell administration. To further define this impact on fibre type composition, the quantitative proteomic approach needed to be supplemented by immuno- as well as enzymo-histochemistry experiments. The relative abundances of slow, fast and intermediate myofibres in skeletal muscle of GRMD and GRMD ${ }^{\text {Mustem }}$ dogs were investigated using MYH7 to label slow fibres. Enzyme-histochemical assays using mATPase were carried out on serial sections (Fig. 3A). While $67.5 \pm 9.6 \%$ of fibres express MYH7 in the GRMD dog, the proportion of $M Y H 7^{+}$fibres in GRMD $^{\text {Mustem }}$ dog is $56.4 \pm 10.0 \%$, revealing no significant decrease of muscle fibres expressing this protein after MuStem cell delivery. This result, associated with the decreased MYH7 expression observed in the ICPL and WB experiments (Fig. 2C), indicates that the cell therapy applied to the GRMD dogs causes a lower abundance of the MYH7 protein without affecting the proportion of $\mathrm{MYH7}^{+}$ fibres. In addition, the mATPase activity staining allows us to classify the fibres into slow, fast and intermediate types. Fig. 3B illustrates the quantification of muscle fibre distribution in GRMD and GRMD $^{\text {Mustem }}$ dogs. No change occurs after MuStem cell transplantation as regards to the abundance of slow and fast fibre types. The percentage of intermediate fibres increases from $18.8 \pm 5.6 \%$ to $27.1 \pm 6.1 \%$ after MuStem cell administration. The results tend to show an increase of intermediate fibres that could reflect an active skeletal muscle regenerative context, since their transitory presence is known to be associated with newly formed fibres characterized by an undefined metabolic status. In accordance with this result, we observe $4.8 \pm 2.4 \%$ of $\mathrm{MyHCd}^{+}$fibres in the GRMD dog and $12.65 \pm 6.64 \%$ in the GRMD ${ }^{\text {Mustem }}$ dogs.

\subsection{Extracellular matrix deposition is increased by MuStem cell transplantation}

Several proteins, more abundant after MuStem cell transplantation, have been identified as part of the "focal adhesion proteome" and "proteinaceous extracellular matrix" and thus seem to indicate an enhancement of the link between skeletal muscle fibre and the extracellular matrix. In the aim to complete our proteomic data and to give information related to the fibrosis status in GRMD and GRMD $^{\text {Mustem }}$ dogs, we added some experiments to investigate the level expression of extracellular matrix proteins in GRMD and GRMD ${ }^{\text {Mustem }}$ dogs. Labelling of Collagen I in muscle transverse sections showed an increase in the collagen I amount and a heterogeneous thickening of the endomysial compartment between fibers in GRMD dogs compared to control healthy dogs (Fig. 4A). Conversely, GRMD $^{\text {Mustem }}$ displayed a generalized and more homogeneous thickening of the endomysial tissue. The peri- and endo-mysial compartment represent $15.3 \pm 3.2 \%, 21.4 \pm 3.5 \%, 29.0 \pm 3.9 \%$ of the total muscle area, respectively for the healthy, GRMD and GRMD ${ }^{\text {Mustem }}$ dog. There is a group effect ( $F=$ 
$11.059 ; P<0.0001)$, the collagen I content is higher in the GRMD group $(P<0.05)$ and GRMD ${ }^{\text {Mustem }}$ $(P<0.05)$ compared with healthy dog muscle. In addition, relative to the GRMD group, collagen I content is higher in the GRMD ${ }^{\text {Mustem }}$ group $(P<0.05)$. To quantify the total collagenic content (endo-, peri- and epi- mysial content), Hyp concentrations in biceps femoris muscles of healthy, GRMD and $G$ RMD $^{\text {Mustem }}$ dogs are shown in Figure 4B. There is a group effect $(F=69.378 ; P<0.0001)$, the Hyp concentration is higher in the GRMD group $(P<0.0001)$ and GRMD ${ }^{\text {Mustem }}(P<0.0001)$ compared with healthy dog muscle. In addition, relative to the GRMD group, Hyp concentration is higher in the GRMD $^{\text {Mustem }}$ group $(P<0.0001)$.

\section{Discussion}

To design an accurate model of the transcriptome and proteome variations due to MuStem cell administration, we make use of the microarray and ICAT quantitative proteomic approaches applied previously to studying GRMD dog muscle $[10,16]$. In this clinically relevant DMD animal model, our previous studies reveal alterations of intracellular signalling defects, energy metabolism, inflammatory response and extracellular matrix organization occur in the pathophysiological process of the disease. Over the last ten years, several adult stem cell populations have been engrafted into the GRMD dog model and characterized as exhibiting myogenic regenerative potential [50]. We have recently shown that systemic delivery of MuStem cells generates beneficial clinical and tissue impacts in the GRMD dog [38]. Also, we implemented the remodelling of dystrophic muscle tissue by demonstrating the induction of differential gene expression profiling at the transcript level [10]. In the present study, we use a large-scale quantitative proteomic approach to complement these observations at the protein level.

Multi-level analyses simultaneously investigate the transcriptome and the proteome of the tissue, and thus have greater potential for providing information on the biological pathways impacted by cell therapy. However, it is noteworthy that, among the 25 proteins over-expressed following cell transplantation, only ITIH4 was identified in our previous transcriptomic study, where it was also shown to be over-expressed [10]. Similarly, among the 46 proteins identified as under-expressed, only $\mathrm{MYH} 2, \mathrm{MYH} 4$ and $\mathrm{MYH} 7$ were identified at a transcriptomic level, and were conversely shown to be over-expressed. The combination of these data indicates that the expression of these three myosin genes seems to be post-transcriptionally expressed. Furthermore, in terms of biological processes impacted by the treatment, we observe that the results from both approaches are highly complementary, highlighting the importance of performing tissue exploration at several levels of gene expression. Our global analysis reveals that intra-arterial delivery of MuStem cell results in altered expression levels of proteins implicated in the different steps of the muscle repair process as described below.

4.1 MuStem cell administration enhances protection of skeletal muscle cells against oxidative stress

We observe that the expression of key enzymes involved in the cellular oxidative stress response is modified after MuStem cell administration. Among these, the ferritin and haptoglobin (HP) proteins are over-expressed. Ferritin is known to perform functions in the rapid detoxification of iron, as well 
as its nucleation, mineralization and long-term storage [51,52]. In addition, this protein plays a role in lowering the intracellular concentration of reactive oxygen species (ROS) [53]. Iron upregulates ferritin for protecting skeletal muscle cells against oxidative stress. The expression of iron-storage ferritin light chain in GRMD ${ }^{\text {Mustem }}$ dog muscle can induce compensatory mechanisms to minimize the potential stress of iron overload in dystrophic tissue. Skeletal muscle can convert the highly reactive ferrous iron, using ferritin heavy chain, into the less reactive ferric iron, and subsequently store ferric iron, using ferritin light chain $[54,55]$. In our experiment, we confirm the overrepresentation after MuStem cell transplantation by immunoblotting with a ferritin light chain antibody.

HP is a plasmatic glycoprotein produced by hepatocytes and adipocytes, which is involved in the acute phase of inflammation. Interestingly, a study on knockout mice $\left(\mathrm{Hp}^{-/}\right)$has revealed that absence of HP causes muscle atrophy and weakness due to the activation of an atrophy program. When animals are stressed, autophagy-lysosome and ubiquitin-proteasome systems are induced. Under pro-oxidative conditions such as with systemic inflammation, HP is required to prevent oxidative stress and the activation of pathways leading to muscle atrophy and weakness [56]. Thus, the overrepresentation of these two proteins in GRMD ${ }^{\text {Mustem }}$ dogs as compared to GRMD dogs suggests that MuStem cell administration protects skeletal muscle against oxidative stress associated with a DMD context. Indeed, a novel role in oxidative stress regulation has been described for gelsolin [57]. Interestingly, expression of the gelsolin protein is low in the naturally protected extraocular muscles from $m d x$ mouse [58]. These low levels of gelsolin in $m d x$ muscle could limit the stress response, and an adaptive mechanism might cause the sparing of extraocular fibre. After MuStem cell treatment, a reversal is observed in the expression of gelsolin from the initial overrepresentation detected in the pathological context. This implies that gelsolin is a potential biomarker, especially considering that muscle is the major source of plasma gelsolin, where this protein is highly concentrated.

\subsection{MuStem cell administration induces the initial phase of muscle repair}

The early phase of muscle injury is usually accompanied by the infiltration of inflammatory cells into the damaged tissue. Among the 25 proteins under-expressed in the skeletal muscle of GRMD ${ }^{\text {Mustem }}$ dogs as compared to GRMD dogs, 7 proteins are identified as being involved in inflammatory response. The enrichment of this term of the Gene Ontology includes the proteins ITIH4, FGB and C3, which seem to reflect the acute phase response characterized by inflammation and degeneration of the damage tissue, described as the initial phase of muscle repair [59]. Annexin A1 and A5 (ANXA1 and ANXA5), described as playing a role in inflammation modulation, are also over-expressed following our cell therapy approach. In parallel, it is known that ANXA1 may contribute to the regeneration of skeletal muscle tissue, thus corroborating our data indicating a stimulation of muscle fibre regeneration subsequent to MuStem cell delivery [60].

4.3 MuStem cell administration stimulates a global modification of the fibre type composition in the GRMD dog skeletal muscle

Skeletal muscle is composed of several fibre types. Muscle fibres are dynamic structures capable of responding to distinct physiological conditions and to a variety of signals by changing their phenotypic profiles. The changes in myosin heavy chain ( $\mathrm{MyHC}$ ) isoforms tend to follow a general pattern of sequential and reversible transitions from fast-to-slow and slow-to-fast [61]. The adaptive ranges 
of different fibres vary depending on the basal protein isoform profile, and hence their position within the fast-slow spectrum. Fibre-type composition is a determining factor for muscle properties, and numerous data indicate that the fast-twitch fibres are more prone to damage in DMD patients, whereas the slow-twitch fibres are relatively unaffected during a first stage. A switch to slow fibres has been described as reducing the muscle atrophy gene expression program and improving the DMD phenotype [62].

In the present study, we demonstrate that numerous structural components of proteins such as fibre-type specific markers are differentially expressed after MuStem cell transplantation, in association with MyHC. In a DMD context, it is established that fast-twitch fibres are predominantly affected and progressively replaced by slow-twitch and intermediate fibres [63], in agreement to the Howald theory [64]. Following the MuStem cell transplantation, mATPase staining reveals a trend towards a decreased abundance of fast-twitch fibres and an increase of intermediate fibres. This is confirmed at protein level by a concomitant underrepresentation of fast-twitch fibre markers MYH4, TNNT3 and an overrepresentation of TAGLN, as has been described in rabbit Tibialis anterior muscle as a marker of fast-to-slow fibre transition process [46]. Collectively, these expression changes, which are identified as being consequent to the MuStem cell-based therapy, may be of interest as a strategy to promote fast-to-slow fibre transformation in DMD patients, and have been evoked to reduce morbidity and prolong life [65]. In parallel, it is surprising to note a slight trend towards a lower percentage of slow-twitch fibres combined with an underrepresentation of slow-twitch fibretype markers such as MyH7, TNNT1. We also demonstrate an overrepresentation of FABP4, which has been described to be highly expressed in skeletal muscle of endurance-trained individuals [49]. Overall, these original results suggest an overall change in the expression of proteins specific to the different fibre types, which, intriguingly, do not seem to be associated with a clear transition of fibre type. We could hypothesize that the delay of five months between the transplantation protocol and the histological exploration is too short to allow the detection of a clear change in fibre type composition. In addition, it can be argued that the increased proportion of intermediate fibres representative of this transition step also reflects the active and persistent regenerative process observed in GRMD $^{\text {Mustem }}$ muscles.

MuStem cell infusion induces an increased integrity of muscle fascicle. Regarding the notion of muscle tissue remodelling, it is noteworthy that functional analysis identifies an enrichment of the Gene Ontology (GO) term striated muscle cell differentiation in the group of proteins underrepresented following MuStem cell administration. The GO terms actin cytoskeleton organization as well as the sarcomere organization are also found to be over-represented in the group of proteins underexpressed in GRMD ${ }^{\text {Mustem }}$ skeletal muscle as compared to the GRMD dog samples. Interestingly, the gelsolin, an actin binding protein, which mediates the remodelling of actin filaments, is overexpressed in GRMD dog muscle and reversed after MuStem cell therapy. In parallel, the ARPC3 and ARPC4 components of the ARP2/3 complex are over-expressed after MuStem cell administration. Indeed, these components are involved in the regulation of actin polymerization and in the formation of branched actin networks. The structural organization of the skeletal muscle fibres thus seems to be modified by the MuStem cell therapy. Furthermore, several proteins over-expressed after MuStem cell transplantation have been identified as part of the focal adhesion proteome in human fibroblasts (YWHAZ, TAGLN, B2M, ANXA1 and ANXA5) [66] and thus seem to indicate an en- 
hancement of the link between skeletal muscle fibre and the extracellular matrix. We observed that MuStem cell transplantation increases extracellular matrix deposition and collagen abundance. We hypotheses that increase of extracellular matrix components could be temporary and may stabilize the skeletal muscle tissue and act as a scaffold for the new fibres [59].

This may reflect an increased stability of muscle fibres and thus a reduction in the need of renewal of these fibres in the GRMD ${ }^{\text {Mustem }}$ dog as compared to the GRMD dog. Nevertheless, fibre regeneration is still active as shown by the presence of $\mathrm{MyHCd}^{+}$fibres in skeletal muscle of $\mathrm{GRMD}^{\text {Mustem }}$ samples, suggesting that increased muscle fibre integrity and muscle repair coexist after MuStem cell transplantation [10].

Taken together, these results suggest that the transplantation of MuStem cells has an impact on the cytoskeletal organization and cell adhesion through a remodelling of the protein composition of focal adhesions between the cells and the underlying extracellular matrix. Considering all the results, this study shows that MuStem cell transplantation leads to a preservation of the organization of myofibre bundles.

\subsection{MuStem cell administration promotes paracrine effect}

The enrichment of the $\mathrm{GO}$ term extracellular vesicular exosome in GRMD ${ }^{\text {Mustem }}$ dogs compared to GRMD dogs is due to the presence of proteins that are identified as being localized in exosomes. Among them, we find proteins involved in redox homeostasis, inflammation modulation, immunity and membrane repair. This enrichment of this $\mathrm{GO}$ term is intriguing with regard to the paracrine effect of mesenchymal stem cells (MSC), since this effect is partly mediated by exosomes, secreted vesicles that have recently been described as being implicated in skeletal muscle regeneration after MSC transplantation [67].

\section{Conclusions}

In this study, we use a quantitative proteomic approach to characterize protein expression changes in the skeletal muscle of GRMD dogs caused by MuStem cell administration. We show that MuStem cell infusion through intra-arterial delivery i) contributes to a structural remodelling of the skeletal muscle, illustrated by an increased proportion of $\mathrm{MyHCd}^{+}$fibres and improved integrity of the muscle fascicles; ii) promotes the setting-up of protective mechanisms against oxidative stress related to the DMD context; and iii) favours the initial phase of muscle repair. Part of these effects may be mediated through paracrine pathways implicating exosomes. The exploration of the impact of MuStem cells on dystrophic skeletal muscle tissue using an undedicated approach provides new insights into the understanding of the biological processes underlying the efficacy of this cell therapy on skeletal muscle.

\section{Acknowledgements}

We thank Emmanuelle Com for stimulating discussions relative to the LC-MS/MS analysis. This research was funding by grant from the "Association Française contre les Myopathies" (AFM N¹4379) 
and the FEDER (Fonds Européens de Développement Régional N³7085). It was carried out in the context of the IHU-Cesti project that received French government financial support managed by the National Research Agency via the investment for the future programme ANR-10-IBHU-005. The IHUCesti project is also supported by Nantes Metropole and the Pays de la Loire Region.

The authors have declared no conflict of interest

\section{Author Contributions}

L.G prepared the protein extracts, M.L.R., B.G. and L.G. processed the ICPL experiment and M.L.R. performed the protein identification and relative quantification. A.L. analysed the ICPL data. S.J. and M.L performed the immuno and enzymo-histochemistry. S.J, L.D and T.L. participated to the histomorphometric analysis. C.P. participated to design the proteomic research. A.L., L.G. and K.R. interpreted the ICPL data. The manuscript was written through contributions of all authors. All authors have given approval to the final version of the manuscript. (M.L.R. Mélanie Lagarrigue; M.L. Mireille Ledevin)

\section{References}

[1] Moat, S.J., Bradley, D.M., Salmon, R., Clarke, A., Hartley, L., Newborn bloodspot screening for Duchenne muscular dystrophy: 21 years experience in Wales (UK). Eur. J. Hum. Genet. 2013, 21, 1049-53.

[2] Hoffman, E.P., Brown, R.H., Kunkel, L.M., Dystrophin: the protein product of the Duchene muscular dystrophy locus. 1987. Biotechnology 1992, 24, 457-466.

[3] Ervasti, J.M., Campbell, K.P., Membrane organization of the dystrophin-glycoprotein complex. Cell 1991, 66, 1121-31.

[4] Haslett, J.N., Sanoudou, D., Kho, A.T., Han, M., et al., Gene expression profiling of Duchenne muscular dystrophy skeletal muscle. Neurogenetics 2003, 4, 163-171.

[5] Pescatori, M., Broccolini, A., Minetti, C., Bertini, E., et al., Gene expression profiling in the early phases of DMD: a constant molecular signature characterizes DMD muscle from early postnatal life throughout disease progression. FASEB J. 2007, 21, 1210-1226.

[6] Tkatchenko, A. V, Le Cam, G., Léger, J.J., Dechesne, C.A., Large-scale analysis of differential gene expression in the hindlimb muscles and diaphragm of mdx mouse. Biochim. Biophys. Acta 2000, 1500, 17-30.

[7] Rouger, K., Le Cunff, M., Steenman, M., Potier, M.-C., et al., Global/temporal gene expression in diaphragm and hindlimb muscles of dystrophin-deficient (mdx) mice. Am. J. Physiol. Cell Physiol. 2002, 283, C773-84.

[8] Porter, J.D., Merriam, A.P., Leahy, P., Gong, B., Khanna, S., Dissection of temporal gene expression signatures of affected and spared muscle groups in dystrophin-deficient (mdx) mice. Hum. Mol. Genet. 2003, 12, 1813-21.

[9] Porter, J.D., Merriam, A.P., Leahy, P., Gong, B., et al., Temporal gene expression profiling of dystrophin-deficient (mdx) mouse diaphragm identifies conserved and muscle group-specific mechanisms in the pathogenesis of muscular dystrophy. Hum. Mol. Genet. 2004, 13, 257-69.

[10] Robriquet, F., Lardenois, A., Babarit, C., Larcher, T., et al., Differential Gene Expression Profiling of Dystrophic Dog Muscle after MuStem Cell Transplantation. PLoS One 2015, 10, e0123336.

[11] Chen, Y.W., Zhao, P., Borup, R., Hoffman, E.P., Expression profiling in the muscular dystrophies: Identification of novel aspects of molecular pathophysiology. J. Cell Biol. 2000, 151, 1321-1336.

[12] Marotta, M., Ruiz-Roig, C., Sarria, Y., Peiro, J.L., et al., Muscle genome-wide expression profiling during disease evolution in mdx mice. Physiol. Genomics 2009, 37, 119-132.

[13] Holland, A., Ohlendieck, K., Proteomic profiling of the dystrophin-deficient mdx phenocopy of dystrophinopathy- 
associated cardiomyopathy. Biomed Res. Int. 2014, 2014.

[14] Lewis, C., Carberry, S., Ohlendieck, K., Proteomic profiling of x-linked muscular dystrophy. J. Muscle Res. Cell Motil. 2009, 30, 267-279.

[15] Rayavarapu, S., Coley, W., Cakir, E., Jahnke, V., et al., Identification of disease specific pathways using in vivo SILAC proteomics in dystrophin deficient mdx mouse. Mol. Cell. Proteomics 2013, 12, 1061-73.

[16] Guevel, L., Lavoie, J.R., Perez-Iratxeta, C., Rouger, K., et al., Quantitative proteomic analysis of dystrophic dog muscle. J. Proteome Res. 2011, 10, 2465-78.

[17] Cooper, B.J., Winand, N.J., Stedman, H., Valentine, B.A., et al., The homologue of the Duchenne locus is defective in Xlinked muscular dystrophy of dogs. Nature 1988, 334, 154-6.

[18] Valentine, B.A., Cooper, B.J., de Lahunta, A., O’Quinn, R., Blue, J.T., Canine X-linked muscular dystrophy. An animal model of Duchenne muscular dystrophy: clinical studies. J. Neurol. Sci. 1988, 88, 69-81.

[19] Ambrósio, C.E., Fadel, L., Gaiad, T.P., Martins, D.S., et al., Identification of three distinguishable phenotypes in golden retriever muscular dystrophy. Genet. Mol. Res. 2009, 8, 389-96.

[20] Kornegay, J.N., Bogan, J.R., Bogan, D.J., Childers, M.K., et al., Canine models of Duchenne muscular dystrophy and their use in therapeutic strategies. Mamm. Genome 2012, 23, 85-108.

[21] Valentine, B.A., Cooper, B.J., de Lahunta, A., O’Quinn, R., Blue, J.T., Canine X-linked muscular dystrophy: An animal model of Duchenne muscular dystrophy: Clinical studies. J. Neurol. Sci. 1988, 88, 69-81.

[22] Valentine, B.A., Cooper, B.J., Cummings, J.F., de Lahunta, A., Canine X-linked muscular dystrophy: morphologic lesions. J. Neurol. Sci. 1990, 97, 1-23.

[23] Gaiad, T.P., Araujo, K.P.C., Serrão, J.C., Miglino, M.A., Ambrósio, C.E., Motor physical therapy affects muscle collagen type I and decreases gait speed in dystrophin-deficient dogs. PLoS One 2014, 9, e9350o.

[24] Barthélémy, I., Pinto-Mariz, F., Yada, E., Desquilbet, L., et al., Predictive markers of clinical outcome in the GRMD dog model of Duchenne muscular dystrophy. Dis. Model. Mech. 2014, 7, 1253-61.

[25] Heslop, L., Morgan, J.E., Partridge, T. a, Evidence for a myogenic stem cell that is exhausted in dystrophic muscle. J. Cell Sci. 2000, 113 ( Pt 1, 2299-2308.

[26] Collins, C.A., Morgan, J.E., Duchenne's muscular dystrophy: Animal models used to investigate pathogenesis and develop therapeutic strategies. Int. J. Exp. Pathol. 2003, 84, 165-172.

[27] Skuk, D., Goulet, M., Roy, B., Piette, V., et al., First test of a "high-density injection" protocol for myogenic cell transplantation throughout large volumes of muscles in a Duchenne muscular dystrophy patient: eighteen months follow-up. Neuromuscul. Disord. 2007, 17, 38-46.

[28] Sampaolesi, M., Blot, S., D’Antona, G., Granger, N., et al., Mesoangioblast stem cells ameliorate muscle function in dystrophic dogs. Nature 2006, 444, 574-579.

[29] Dellavalle, A., Sampaolesi, M., Tonlorenzi, R., Tagliafico, E., et al., Pericytes of human skeletal muscle are myogenic precursors distinct from satellite cells. Nat. Cell Biol. 2007, 9, 255-267.

[30] Meng, J., Chun, S., Asfahani, R., Lochmüller, H., et al., Human skeletal muscle-derived CD133(+) cells form functional satellite cells after intramuscular transplantation in immunodeficient host mice. Mol. Ther. 2014, 22, 1008-17.

[31] Lewis, F.C., Henning, B.J., Marazzi, G., Sassoon, D., et al., Porcine skeletal muscle-derived multipotent PWipos/Pax7neg interstitial cells: isolation, characterization, and long-term culture. Stem Cells Transl. Med. 2014, 3, 702-12.

[32] Vella, J.B., Thompson, S.D., Bucsek, M.J., Song, M., Huard, J., Murine and human myogenic cells identified by elevated aldehyde dehydrogenase activity: Implications for muscle regeneration and repair. PLoS One 2011, 6.

[33] Shabbir, A., Zisa, D., Leiker, M., Johnston, C., et al., Muscular dystrophy therapy by nonautologous mesenchymal stem cells: muscle regeneration without immunosuppression and inflammation. Transplantation 2009, 87, 1275-1282.

[34] Lavasani, M., Lu, A., Thompson, S.D., Robbins, P.D., et al., Isolation of muscle-derived stem/progenitor cells based on adhesion characteristics to collagen-coated surfaces. Methods Mol. Biol. 2013, 976, 53-65.

[35] Chirieleison, S.M., Feduska, J.M., Schugar, R.C., Askew, Y., Deasy, B.M., Human Muscle-Derived Cell Populations 
Isolated by Differential Adhesion Rates: Phenotype and Contribution to Skeletal Muscle Regeneration in Mdx/SCID Mice. Tissue Eng. Part A 2012, 18, 232-241.

[36] Chargé, S.B.P., Rudnicki, M.A., Cellular and molecular regulation of muscle regeneration. Physiol. Rev. 2004, 84, $209-38$.

[37] Mourkioti, F., Rosenthal, N., IGF-1, inflammation and stem cells: interactions during muscle regeneration. Trends Immunol. 2005, 26, 535-42.

[38] Rouger, K., Larcher, T., Dubreil, L., Deschamps, J.-Y., et al., Systemic delivery of allogenic muscle stem cells induces long-term muscle repair and clinical efficacy in duchenne muscular dystrophy dogs. Am. J. Pathol. 2011, 179, 2501-18.

[39] Chalmel, F., Primig, M., The Annotation, Mapping, Expression and Network (AMEN) suite of tools for molecular systems biology. BMC Bioinformatics 2008, 9, 86.

[4o] Sarioglu, H., Brandner, S., Jacobsen, C., Meindl, T., et al., Quantitative analysis of 2,3,7,8-tetrachlorodibenzo-p-dioxininduced proteome alterations in $5 \mathrm{~L}$ rat hepatoma cells using isotope-coded protein labels. Proteomics 2006, 6, 2407-21.

[41] Com, E., Clavreul, A., Lagarrigue, M., Michalak, S., et al., Quantitative proteomic Isotope-Coded Protein Label (ICPL) analysis reveals alteration of several functional processes in the glioblastoma. J. Proteomics 2012, 75, 3898-913.

[42] Smyth, G.K., Linear models and empirical bayes methods for assessing differential expression in microarray experiments. Stat. Appl. Genet. Mol. Biol. 2004, 3, Article3.

[43] Schindelin, J., Arganda-Carreras, I., Frise, E., Kaynig, V., et al., Fiji: an open-source platform for biological-image analysis. Nat. Methods 2012, 9, 676-682.

[44] Vizcaíno, J., Deutsch, E., Wang, R., ProteomeXchange provides globally coordinated proteomics data submission and dissemination. Nat. ... 2014, 32, 223-226.

[45] Kang, J., Albadawi, H., Patel, V.I., Abbruzzese, T.A., et al., Apolipoprotein E-/- mice have delayed skeletal muscle healing after hind limb ischemia-reperfusion. J. Vasc. Surg. 2008, 48, 701-8.

[46] Donoghue, P., Doran, P., Wynne, K., Pedersen, K., et al., Proteomic profiling of chronic low-frequency stimulated fast muscle. Proteomics 2007, 7, 3417-3430.

[47] Jaenicke, T., Diederich, K.W., Haas, W., Schleich, J., et al., The complete sequence of the human $\beta$-myosin heavy chain gene and a comparative analysis of its product. Genomics 1990, 8, 194-206.

[48] Wei, B., Jin, J.P., Troponin T isoforms and posttranscriptional modifications: Evolution, regulation and function. Arch. Biochem. Biophys. 2011, 505, 144-154.

[49] Fischer, H., Gustafsson, T., Sundberg, C.J., Norrbom, J., et al., Fatty acid binding protein 4 in human skeletal muscle. Biochem. Biophys. Res. Commun. 2006, 346, 125-130.

[5o] Negroni, E., Gidaro, T., Bigot, A., Butler-Browne, G.S., et al., Invited review: Stem cells and muscle diseases: advances in cell therapy strategies. Neuropathol. Appl. Neurobiol. 2015, 41, 270-87.

[51] Kruszewski, M., in:, Mutat. Res. - Fundam. Mol. Mech. Mutagen., vol. 531, 2003, pp. 81-92.

[52] Lane, D.J.R., Merlot, A.M., Huang, M.L.-H., Bae, D.-H., et al., Cellular iron uptake, trafficking and metabolism: Key molecules and mechanisms and their roles in disease. Biochim. Biophys. Acta 2015, 1853, 1130-1144.

[53] Arosio, P., Levi, S., Cytosolic and mitochondrial ferritins in the regulation of cellular iron homeostasis and oxidative damage. Biochim. Biophys. Acta - Gen. Subj. 2010, 1800, 783-792.

[54] Harrison, P.M., Arosio, P., The ferritins: molecular properties, iron storage function and cellular regulation. Biochim. Biophys. Acta 1996, 1275, 161-203.

[55] Rucker, P., Torti, F.M., Torti, S. V, Role of H and L subunits in mouse ferritin. J. Biol. Chem. 1996, 271, 33352-7.

[56] Bertaggia, E., Scabia, G., Dalise, S., Lo Verso, F., et al., Haptoglobin is required to prevent oxidative stress and muscle atrophy. PLoS One 2014, 9.

[57] Ji, L., Chauhan, A., Chauhan, V., Cytoplasmic gelsolin in pheochromocytoma-12 cells forms a complex with amyloid betaprotein. Neuroreport 2008, 19, 463-6.

[58] Lewis, C., Ohlendieck, K., Proteomic profiling of naturally protected extraocular muscles from the dystrophin-deficient mdx mouse. Biochem. Biophys. Res. Commun. 2010, 396, 1024-9. 
[59] Karalaki, M., Fili, S., Philippou, A., Koutsilieris, M., Muscle Regeneration: Cellular and Molecular Events. In Vivo (Brooklyn). 2009, 23, 779-796.

[6o] Bizzarro, V., Petrella, A., Parente, L., Annexin A1: Novel roles in skeletal muscle biology. J. Cell. Physiol. 2012, 227, 30073015 .

[61] Pette, D., Staron, R.S., Myosin isoforms, muscle fiber types, and transitions. Microsc. Res. Tech. 2000, 50, 500-9.

[62] Chalkiadaki, A., Igarashi, M., Nasamu, A.S., Knezevic, J., Guarente, L., Muscle-specific SIRT1 gain-of-function increases slow-twitch fibers and ameliorates pathophysiology in a mouse model of duchenne muscular dystrophy. PLoS Genet. 2014, 10, e1004490.

[63] Webster, C., Silberstein, L., Hays, A.P., Blau, H.M., Fast muscle fibers are preferentially affected in Duchenne muscular dystrophy. Cell 1988, 52, 503-13.

[64] Howald, H., Training-induced morphological and functional changes in skeletal muscle. Int. J. Sports Med. 1982, 3, 1-12.

[65] Chin, E.R., Olson, E.N., Richardson, J.A., Yang, Q., et al., A calcineurin-dependent transcriptional pathway controls skeletal muscle fiber type. Genes Dev. 1998, 12, 2499-509.

[66] Kuo, J.-C., Han, X., Hsiao, C.-T., Yates, J.R., Waterman, C.M., Analysis of the myosin-II-responsive focal adhesion proteome reveals a role for $\beta$-Pix in negative regulation of focal adhesion maturation. Nat. Cell Biol. 2011, 13, 383-393.

[67] Nakamura, Y., Miyaki, S., Ishitobi, H., Matsuyama, S., et al., Mesenchymal-stem-cell-derived exosomes accelerate skeletal muscle regeneration. FEBS Lett. 2015, 589, 1257-1265.

\section{Legends}

Figure 1. Flow chart showing statistical filtering of the ICPL data when comparing the GRMD ${ }^{\text {Mustem }}$ sample with the GRMD sample. The 492 proteins considered as correctly quantified were filtered and classified into groups of over- and under-expressed proteins.

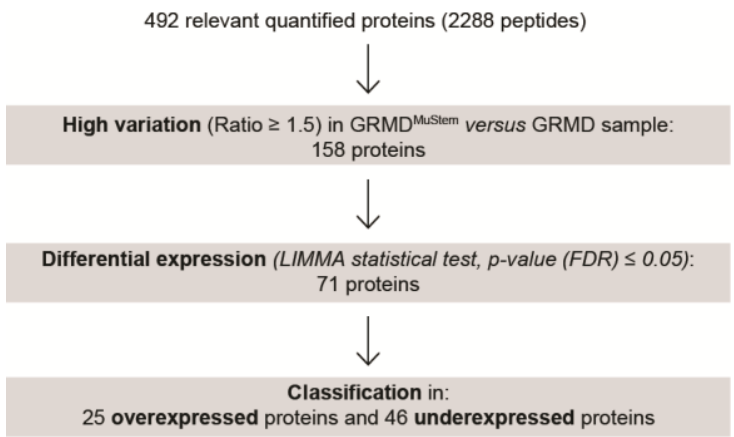

Figure 2. Western immunoblot (WB) analyses of the myosin heavy chain 7 (MYH7), gelsolin (GSN), troponin T type 1 (TNNT1) and ferritin proteins in healthy, GRMD and GRMD ${ }^{\text {Mustem }}$ samples. (A) Representative WB analyses. $\alpha$-actinin is used as control. (B) Graphical representation of immunoblot analyses in three healthy, three GRMD and six GRMD ${ }^{\text {Mustem }}$ samples. The mean fluorescence intensity is represented along with the SEM (standard error of the mean) for the different samples. Statistical significance is estimated with a Mann Whitney test: ${ }^{*}, p<0.05$. (C) Protein quantification by ICPL and by Western blotting. Comparison of ICPL ratio (expressed as non log2-transformed values) with quantification of proteins obtained from Western blotting experiment. 

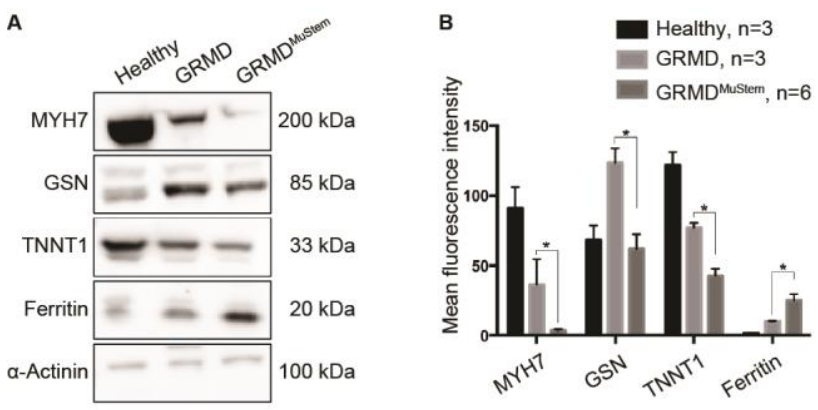

\begin{tabular}{|c|c|c|c|c|c|}
\hline \multirow{2}{*}{$\begin{array}{l}\text { Protein } \\
\text { name }\end{array}$} & \multirow[b]{2}{*}{$\begin{array}{l}\text { ICPL } \\
\text { triplex }\end{array}$} & \multicolumn{4}{|c|}{ GRMDMustem versus GRMD } \\
\hline & & $\begin{array}{l}\text { ICPL } \\
\text { ratio }\end{array}$ & $\begin{array}{l}\text { Average } \\
\text { ICPL ratio }\end{array}$ & $\begin{array}{l}\text { WB } \\
\text { ratio }\end{array}$ & $\begin{array}{l}\text { Average } \\
\text { WB ratio }\end{array}$ \\
\hline \multirow[t]{3}{*}{ MYH7 } & T1 & 0.55 & \multirow{3}{*}{$0.27 \pm 0.25$} & 0.13 & \multirow{3}{*}{$0.23 \pm 0.09$} \\
\hline & T2 & 0.18 & & 0.29 & \\
\hline & T3 & 0.07 & & 0.27 & \\
\hline \multirow{3}{*}{ GSN } & T1 & 0.42 & \multirow{3}{*}{$0.60 \pm 0.20$} & 0.77 & \multirow{3}{*}{$0.70 \pm 0.15$} \\
\hline & T2 & 0.81 & & 0.80 & \\
\hline & T3 & 0.56 & & 0.52 & \\
\hline \multirow[t]{3}{*}{ TNNT1 } & T1 & 0.18 & \multirow{3}{*}{$0.29 \pm 0.33$} & 0.67 & \multirow{3}{*}{$0.65 \pm 0.09$} \\
\hline & T2 & 0.03 & & 0.73 & \\
\hline & T3 & 0.66 & & 0.55 & \\
\hline \multirow[t]{3}{*}{ Ferritin } & T1 & 20.97 & \multirow{3}{*}{$11.65 \pm 8.07$} & 4.08 & \multirow{3}{*}{$3.01 \pm 1.00$} \\
\hline & T2 & 6.96 & & 2.86 & \\
\hline & T3 & 7.01 & & 2.09 & \\
\hline
\end{tabular}

Figure 3. Muscle fibre composition in skeletal muscle from GRMD dog sample and GRMD ${ }^{\text {Mustem }}$ dog sample. (A) Expression pattern of MYH7, MyHCd by serial-labelling and histochemical assay for myofibrillar ATPase (mATPase) activity at pH 4.35. The slow type I fibres stain black, whereas fast type IIb muscle fibres remain colorless and intermediate type lla fibres stain in shades of grey. Scale bars: $100 \mu \mathrm{m}$ for all panels. (B) Percentage of slow, fast and intermediate muscle fibre are determined in GRMD and GRMD ${ }^{\text {Mustem }}$ skeletal muscle based on the mATPase staining cryosection. Black and grey bars indicate GRMD and GRMD ${ }^{\text {Mustem }}$ samples respectively.
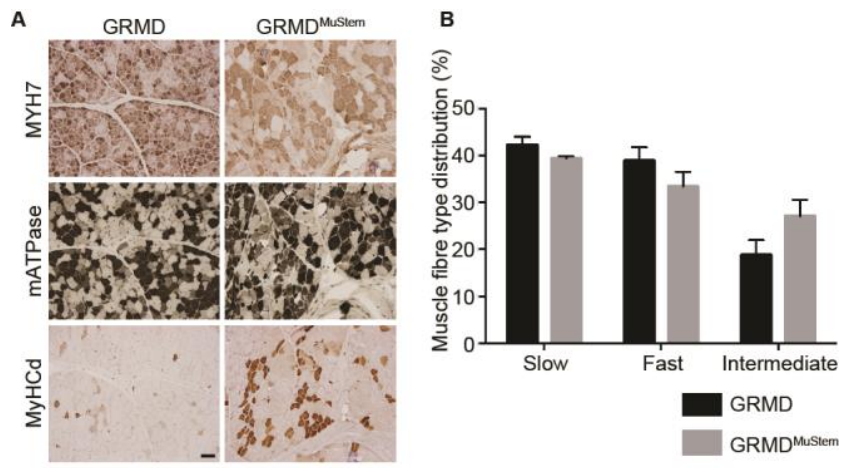

Figure 4. Collagen quantification in dog skeletal muscle. (A) Immunofluorescent labelling of collagen I in biceps femoris muscle of 9-month old dogs. Representative pictures of Healthy, GRMD and GRMD $^{\text {Mustem }}$ dog muscles are presented respectively in left, mid and right panel. Compared to the control muscle (left panel), GRMD dog muscle displayed a diffuse and irregular thickening of endomysial tissue (middle pannel). Conversly, GRMD ${ }^{\text {Mustem }}$ dog muscle (right panel) displayed a more homogeneous and generalized thickening of endomysial tissue. Scale bar $=100 \mu \mathrm{m}$. (B) Mean concentration of hydroxyproline (Hyp) in Healthy, GRMD and GRMD ${ }^{\text {Mustem }}$ dog muscle. 

Healthy GRMD GRMD ${ }^{\text {Mustem }}$

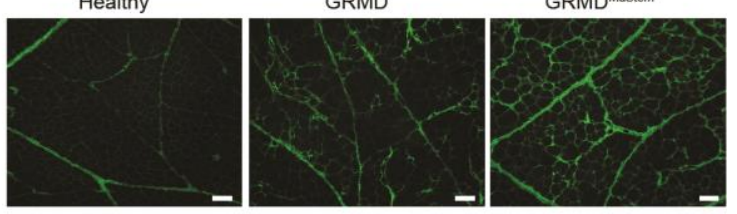

B

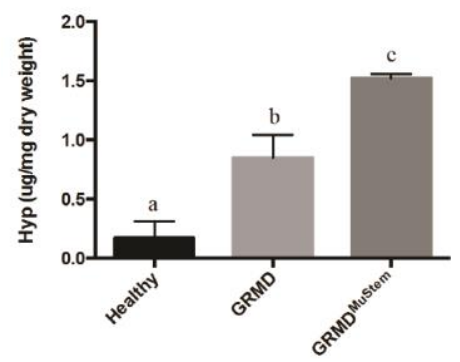

Tables

Table 1. Proteins overrepresented in skeletal muscle of GRMD dogs after MuStem cell administration.

\begin{tabular}{|c|c|c|c|c|}
\hline $\begin{array}{l}\text { UniProt } \\
\text { accession }\end{array}$ & $\begin{array}{l}\text { Median of log2-ratio } \\
\text { GRMD }{ }^{\text {Mustem }} \text { vs. } \\
\text { GRMD }\end{array}$ & $\begin{array}{l}\text { Gene } \\
\text { name }\end{array}$ & Description & $\begin{array}{l}\text { GRMD vs. } \\
\text { Healthy }\end{array}$ \\
\hline P18649 & 3.00 & APOE & apolipoprotein $\mathrm{E}$ & up \\
\hline F6V790 & 1.87 & CILP & $\begin{array}{l}\text { cartilage intermediate layer protein, nucleotide } \\
\text { pyrophosphohydrolase }\end{array}$ & up \\
\hline F1PFZ7 & 1.64 & HIST2H2AC & histone $\mathrm{H} 2 \mathrm{~A}$ type 2 -C-like & - \\
\hline E2RMZ3 & 1.61 & - & ferritin & up \\
\hline E2R974 & 1.55 & FABP4 & fatty acid binding protein 4 , adipocyte & - \\
\hline E2RCC8 & 1.48 & - & uncharacterized protein & up \\
\hline E2RQ14 & 1.31 & ANXA5 & annexin A5 & up \\
\hline P38486 & 1.25 & LGALS3 & galectin-3 & up \\
\hline P19006 & 1.24 & $\mathrm{HP}$ & haptoglobin & up \\
\hline F1PXG4 & 1.08 & ANXA4 & annexin A4 & up \\
\hline F1PC56 & 1.04 & THAP4 & THAP domain-containing protein 4 & down \\
\hline H9GWY3 & 1.02 & ITIH4 & $\begin{array}{l}\text { inter-alpha-trypsin inhibitor heavy chain family, } \\
\text { member } 4\end{array}$ & up \\
\hline
\end{tabular}




\begin{tabular}{|c|c|c|c|c|}
\hline F1PBL1 & 0.98 & YWHAZ & $\begin{array}{l}\text { tyrosine 3-monooxygenase/tryptophan 5- } \\
\text { monooxygenase activation protein, zeta poly- } \\
\text { peptide }\end{array}$ & - \\
\hline E2QWU0 & 0.88 & ARPC4 & actin related protein $2 / 3$ complex, subunit 4 & up \\
\hline E2RIF3 & 0.88 & TAGLN & transgelin & - \\
\hline H9GW68 & 0.76 & OGDH & $\begin{array}{l}\text { oxoglutarate (alpha-ketoglutarate) } \\
\text { dehydrogenase (lipoamide) }\end{array}$ & down \\
\hline F1P6B7 & 0.73 & ANXA1 & annexin $\mathrm{A} 1$ & up \\
\hline F1PGM1 & 0.72 & C3 & complement component 3 & up \\
\hline E2RN10 & 0.72 & $\mathrm{~B} 2 \mathrm{M}$ & beta-2 microglobulin & up \\
\hline $\mathrm{E} 2 \mathrm{RQ} 22$ & 0.68 & COQ9 & $\begin{array}{l}\text { ubiquinone biosynthesis protein COQ9, mito- } \\
\text { chondrial isoform } 1\end{array}$ & down \\
\hline F6XQ29 & 0.67 & H3F3B & histone $\mathrm{H} 3$ & up \\
\hline F1PK29 & 0.67 & RNH1 & ribonuclease/angiogenin inhibitor 1 & up \\
\hline F1PW65 & 0.66 & FGB & fibrinogen beta chain & up \\
\hline H9GW87 & 0.63 & TALDO1 & transaldolase 1 & up \\
\hline J9P309 & 0.59 & ARPC3 & actin-related protein $2 / 3$ complex subunit 3 & up \\
\hline
\end{tabular}

Table 2. Proteins underrepresented in skeletal muscle of GRMD dogs after MuStem cell administration.

\begin{tabular}{|l|l|l|l|l|}
\hline $\begin{array}{l}\text { UniProt } \\
\text { accession }\end{array}$ & $\begin{array}{l}\text { Median of log2-ratio } \\
\text { GRMD }\end{array}$ & Gene name & Description & $\begin{array}{l}\text { GRMD vs. } \\
\text { Healthy }\end{array}$ \\
\hline F1PGU1 & -3.52 & MYLPF & $\begin{array}{l}\text { myosin regulatory light chain 2, skeletal muscle } \\
\text { isoform type 2-like }\end{array}$ & down \\
\hline F1PVC1 & -2.86 & ACTA1 & actin, alpha 1, skeletal muscle & down \\
\hline Q8WN71 & -2.75 & MYL2 & myosin, light chain 2, regulatory, cardiac, slow & down \\
\hline F1PLD6 & -2.63 & TNNI1 & troponin I type 1 (skeletal, slow) & - \\
\hline J9NV52 & -2.47 & TNNT1 & troponin T type 1 (skeletal, slow) & down \\
\hline P49824 & -2.44 & MYH7 & $\begin{array}{l}\text { myosin, heavy chain 7, cardiac muscle, be- } \\
\text { ta;myosin heavy chain slow isoform }\end{array}$ & down \\
\hline
\end{tabular}




\begin{tabular}{|c|c|c|c|c|}
\hline Q076A7 & -1.86 & MYH2;MYH1 & $\begin{array}{l}\text { myosin, heavy chain } 2 \text {, skeletal muscle, } \\
\text { adult;fast myosin heavy chain } 2 \mathrm{~A}\end{array}$ & down \\
\hline F1PQ35 & -1.77 & ME3 & $\begin{array}{l}\text { malic enzyme } 3 \text {, NADP(+)-dependent, mito- } \\
\text { chondrial }\end{array}$ & down \\
\hline E2R072 & -1.55 & MYBPC2 & myosin binding protein C, fast type & down \\
\hline J9P9H8 & -1.53 & LOC100855558 & hemoglobin subunit alpha-like & up \\
\hline E2R7W7 & -1.37 & MAP2K6 & mitogen-activated protein kinase kinase 6 & down \\
\hline E2R8F7 & -1.18 & MYL3 & $\begin{array}{l}\text { myosin, light chain 3, alkali; ventricular, skele- } \\
\text { tal, slow }\end{array}$ & down \\
\hline F1PX65 & -1.15 & PHKB & phosphorylase kinase, beta & down \\
\hline F1Q3Y2 & -1.13 & DPYSL3 & dihydropyrimidinase-like 3 & up \\
\hline E2RBI2 & -1.11 & SLC25A12 & $\begin{array}{l}\text { solute carrier family } 25 \text { (aspartate/glutamate } \\
\text { carrier), member } 12\end{array}$ & down \\
\hline F6X6K8 & -1.07 & LRPPRC & $\begin{array}{l}\text { leucine-rich pentatricopeptide repeat contain- } \\
\text { ing }\end{array}$ & down \\
\hline F1PLS4 & -1.05 & VIM & vimentin & up \\
\hline E2ROZ6 & -1.03 & $\mathrm{JPH} 1$ & junctophilin 1 & - \\
\hline E2R3P7 & -1.02 & RNF123 & ring finger protein 123 & down \\
\hline F1PIA6 & -1.01 & AMPD1 & $\begin{array}{l}\text { adenosine monophosphate deaminase } 1 \text { (iso- } \\
\text { form } M \text { ) }\end{array}$ & - \\
\hline E2R4F8 & -0.97 & NDUFS1 & $\begin{array}{l}\text { NADH dehydrogenase (ubiquinone) Fe-S pro- } \\
\text { tein } 1,75 \mathrm{kDa} \text { (NADH-coenzyme Q reductase) }\end{array}$ & down \\
\hline F1Q104 & -0.94 & CACNA2D1 & $\begin{array}{l}\text { calcium channel, voltage-dependent, alpha } \\
2 / \text { delta subunit } 1\end{array}$ & - \\
\hline F6X895 & -0.90 & SLC25A4 & $\begin{array}{l}\text { solute carrier family } 25 \text { (mitochondrial carrier; } \\
\text { adenine nucleotide translocator), member } 4\end{array}$ & down \\
\hline Q076A5 & -0.86 & $\mathrm{MYH4}$ & $\begin{array}{l}\text { myosin, heavy chain 4, skeletal muscle;fast } \\
\text { myosin heavy chain 2B }\end{array}$ & down \\
\hline F1PX75 & -0.85 & LOC484335 & $\begin{array}{l}\text { serine/threonine-protein phosphatase } 2 \mathrm{~A} 65 \\
\text { kDa regulatory subunit A alpha isoform-like }\end{array}$ & - \\
\hline F1PIY8 & -0.85 & TRIP10 & thyroid hormone receptor interactor 10 & - \\
\hline
\end{tabular}




\begin{tabular}{|c|c|c|c|c|}
\hline F6Y3P9 & -0.84 & GSN & gelsolin & up \\
\hline F6UPH0 & -0.83 & $\mathrm{HRC}$ & histidine rich calcium binding protein & - \\
\hline F1P9J3 & -0.83 & MYH9 & $\begin{array}{l}\text { myosin, heavy chain 9, non-muscle;NMMHC II- } \\
\text { a }\end{array}$ & up \\
\hline E2RQ92 & -0.82 & CPT1B & carnitine palmitoyltransferase 1B (muscle) & - \\
\hline F1PAZ2 & -0.80 & HK2 & hexokinase 2 & - \\
\hline E2RIG0 & -0.80 & LOC608244 & $\begin{array}{l}\text { NADH dehydrogenase [ubiquinone] } 1 \text { alpha } \\
\text { subcomplex subunit 10, mitochondrial-like }\end{array}$ & down \\
\hline F1PXY4 & -0.75 & SLC25A3 & $\begin{array}{l}\text { solute carrier family } 25 \text { (mitochondrial carrier; } \\
\text { phosphate carrier), member } 3\end{array}$ & down \\
\hline F1Q3R2 & -0.71 & HSDL2 & hydroxysteroid dehydrogenase like 2 & down \\
\hline E2R238 & -0.71 & SMTNL1 & smoothelin-like 1 & down \\
\hline E2QWC9 & -0.70 & MCCC2 & methylcrotonoyl-CoA carboxylase 2 (beta) & down \\
\hline F1PL53 & -0.67 & ATP1A2 & $\begin{array}{l}\text { ATPase, } \mathrm{Na}+\mathrm{K}+\text { transporting, alpha } 2 \text { polypep- } \\
\text { tide }\end{array}$ & - \\
\hline F1Q3W0 & -0.67 & HNRNPU & $\begin{array}{l}\text { heterogeneous nuclear ribonucleoprotein } \mathrm{U} \\
\text { (scaffold attachment factor } \mathrm{A} \text { ) }\end{array}$ & - \\
\hline E2QX84 & -0.65 & HSPA2 & heat shock $70 \mathrm{kDa}$ protein 2 & down \\
\hline J9P3S8 & -0.64 & COQ10A & coenzyme Q10 homolog A & down \\
\hline E2R9R2 & -0.64 & LOC612644 & cytochrome c oxidase subunit 6B1-like & down \\
\hline F6XIP5 & -0.64 & MYL6B & $\begin{array}{l}\text { myosin, light chain } 6 \mathrm{~B} \text {, alkali, smooth muscle } \\
\text { and non-muscle }\end{array}$ & down \\
\hline E2RL90 & -0.64 & PDHA1 & $\begin{array}{l}\text { pyruvate dehydrogenase E1 component subu- } \\
\text { nit }\end{array}$ & down \\
\hline J9P5S2 & -0.63 & ACADM & $\begin{array}{l}\text { acyl-CoenzymeA dehydrogenase, C- } 4 \text { to C-12 } \\
\text { straight chain }\end{array}$ & down \\
\hline P52784 & -0.60 & PFKM & phosphofructokinase, muscle & - \\
\hline F1PBY3 & -0.60 & TNNT3 & troponin T type 3 (skeletal, fast) & down \\
\hline
\end{tabular}

